\title{
The chemical composition and nutritive value of low-alkaloid varieties of white lupin 1. Seed, cotyledon and seed coat characteristics*
}

\section{Z. Zduńczyk ${ }^{1}$, J. Juśkiewicz', Marianna Flis ${ }^{2}$, R. Amarowicz ${ }^{1}$ and B. Krefft ${ }^{1}$}

\author{
${ }^{\prime}$ Institute of Animal Reproduction and Food Research, Polish Academy of Sciences, \\ Division of Food Science \\ Tuwima 10, 10-718 Olsztyn, Poland \\ ${ }^{2}$ Institute of Animal Nutrition and Feed Management, \\ Olsztyn Academy of Agriculture and Technology \\ Oczapowskiego 5, 10-718 Olsziyn, Poland
}

(Received 24 August 1995; accepted 12 January 1996)

\begin{abstract}
The size, weight and chemical composition of seeds, colyledons and seed coat of threc Polish varieties of low-alkaloid white lupin, Wat, I Ietman and Bardo, were determined in seed samples from the 1992-1994 harvests. In the oldest variety, Wat, the average proportion of the seed coat was nearly $21 \%$, while crude protein content in seeds amounted to $34 \%$ of DM. The newer varieties, Hetman and Bardo, had a lowcr seed coat content (about $18 \%$ ) and contained more protein ( 37 and $38 \%$ DM, respectively). The alkaloid content in Wat seeds was almost $1 \mathrm{mg} / \mathrm{g}$, while the newer varieties had half this amount. Large differences were found in the contents of nutrients and alkaloids, depending on harvest year. Dehulling raised the protein content to $41-46 \%$ DM and significantly decreased the seed fibre content. Large variations in trace element content were found, independent of the lupin variety, most notably in respect to $\mathrm{Mn}, \mathrm{Fe}$ and $\mathrm{Cu}$. The $\mathrm{Mn}$ content of seeds was relativcly high, ranging from 0.44 to $1.45 \mathrm{~g} / \mathrm{kg}$.
\end{abstract}

KEY WORDS: white lupin, chemical composition, cotyledons, seed coat, mineral composition

\section{INTRODUCTION}

White lupin was introduced into agricultural practice in Central Europe much later than yellow or narrow-leaved lupin and, as a consequence is a much

* The study was supported by the Statc Committec for Scientific Research, Project 5 S30503507 
less-known species. To date, only 17 traits of this species have been genetically explored, i.e. less than half the number in ycllow or narrow-leaved lupin (Święcicki, 1993). Breeding progress as the yield of new varieties (Hetman and Bardo), is $6 \%$, i.e. many times below that in other lupin species during the same period (Święcicki, 1993). The potential high yield of white lupin seed protein which, under favourable conditions exceeds $1000 \mathrm{~kg}$ per hectare (Pagowska, 1990 ), justifies the growing interest in the cultivation of this crop and its use as a feedstuff.

The results of Polish experiments have shown that pigs utilize rations containing the seeds of the first low-alkaloid variety of white lupin, Wat, worse than other legumes (Fuchs et al., 1983; Flis et al., 1989). The few studies using newer varieties, Hetman and Bardo (Buraczewska et al., 1994; Smulikowska et al., 1995) indicate that their nutritive value is higher than of the traditional variety. There is, however, insufficient data about the constancy of the seed chemical composition (including alkaloid content), digestibility and utilization of the nutrients of these varieties. The results of analyses carried out to date (Buraczewska et al., 1993; Smulikowska et al., 1995; Wasilewko et al., 1995) indicate, however, that differences in chemical composition, including protein content, even in the seeds of the same variety, can be considerable. The objective of this study was, threfore, to determine the size, weight and chemical composition of low-alkaloid white lupin seeds depending on variety and year of harvest.

\section{MATERIAL AND METHODS}

White lupin seeds were obtained from Polish seed stations (Kosieczyn, Przebędowo and Wiatrowo) situated the western and south-western regions of Poland. Seeds of the Wat and Hetman varieties were from successive harvests in 1992-1994, while Bardo variety seeds were from 1992 and 1994. The characteristics of the basic physical properties, chemical composition of seeds and alkaloid content were determined in 8 samples, while 2 samples from each variety were used to assay the chemical composition of fractions (cotyledons and seed coats).

In order to characterize the size and weight of the seeds, the length, width and thickness of 100 randomly selected seeds were measured and the weight of 1000 seeds recorded. Specific gravity was determined by a standard method based on measuring the volume of water displaced by a sample of 20 seeds of known weight. Weight and specific gravity were determined in ten replicates.

The percentage content of the sced coat was determined manually by scparating the cotyledons and seed coats from a $100 \mathrm{~g}$ sample of seeds. In order to standardize the results and facilitate separation of cotyledons and seed coats, the sample was first dried al $40^{\circ} \mathrm{C}$. 
The chemical composition of the seeds was determined by standard methods (AOAC, 1990). Total alkaloids were determined gravimetrically according to the methods described by Wysocka et al. (1989). The dominant alkaloids in extracts obtained from defatted seeds of the particular varieties were identified by thin-layer chromatography according to Múzquiz et al. (1994). Alkaloid extracts were separated on silica gel plates (Merck) using chloroform: cyclohexane:diethylamine (6:4:1) as the solvent system. Dragendorff's solution was used to visualize the alkaloids on the plate (Stahl, 1969). Raw fibre, NDF, ADF and lignin were determined according to Van Soest and Wine (1967). The cellulose content was computed as the difference between ADF and lignin, while the amount of hemicellulose was calculated as the difference between NDF and ADF. Dietary fibre (DF) was determined by the enzymatic-gravimetric method according to Asp (1983). The content of selected minerals in seeds was determined by the $\Lambda \Lambda \mathrm{S}$ method following mineralization of the samples in an electric oven at $450^{\circ} \mathrm{C}$. Measurements were made using a Pye Unicam Solar 939 spectrophotometer linked with a Philips P-3348 data station.

\section{RESULTS AND DISCUSSION}

Both variety and year of harvest had a significant effect on the size and weight of white lupin seeds (Table 1). The weight of 1000 Wat seeds, depending on year of harvest, ranged from about 250 to about $280 \mathrm{~g}$. Bardo seeds had similar weight, also below $300 \mathrm{~g}$. The size and weight of Hetman seeds varied most. A 1000 -seed sample of this variety weighed from 258 to $466 \mathrm{~g}$. The specific gravity of seeds was, however, a relatively constant trait, ranging from about 1090 to $1230 \mathrm{~kg} / \mathrm{m}^{3}$. This may indicate that variable weight was less a result of differences in size, and more of the degree of development, e.g. of the weight of endosperm.

The seeds of white lupin are larger and heavier than the seeds of other lupin species (Smulikowska et al., 1995). This is why the proportion of cotyledons in the seeds is relatively higher, while that of the seed coat, smaller than in yellow and narrow-leaved lupin (Zduńczyk et al., 1994; Smulikowska et al., 1995). In our studies we found that Wat seeds had an even smaller cotyledon content $(79.1 \%)$ and larger proportion of secd coat $(20.9 \%)$ in comparison with Hetman and Bardo (Table 2). The higher (by about $3 \%$ ) proportion of the seed coat in the weight of seeds was accompanied by a lower content of crude protein (an average $34 \%$ ), crude fat (under 10\%) and higher content of crude fibre (almost 13\%) in the DM of Wat seeds. In the Hetman and Bardo varieties, the proportion of the seed coat was nearly $18 \%$, while the crude protein content was 37 and $38 \%$ of DM, respectively. Buraczewska et al. (1993) and Smulikowska et al. (1995) found similar differences in the protein content of seeds of the analyzed varieties, with 
TABLE 1

Size and mass of seeds of three white lupin cultivars harvested in 1992-1994

\begin{tabular}{|c|c|c|c|}
\hline \multirow{2}{*}{ Item } & \multicolumn{3}{|c|}{ Cultivar } \\
\hline & Wat & Hetman & Bardo \\
\hline \multicolumn{4}{|c|}{ Sample of sceds from harvests in 1992: } \\
\hline lenght & $10.5^{\mathrm{A}} \pm 0.7$ & $9.5^{\mathrm{B}} \pm 1.0$ & $9.6^{\mathrm{B}} \pm 0.0$ \\
\hline breadth & $9.8^{\wedge} \pm 0.6$ & $8.4^{\mathrm{C}} \pm 0.7$ & $8.7^{\mathrm{B}} \pm 0.7$ \\
\hline thickness & $4.3^{\mathrm{B}} \pm 0.3$ & $4.7^{\mathrm{A}} \pm 0.4$ & $4.9^{\mathrm{A}} \pm 0.4$ \\
\hline Mass of 1000 seeds, $g$ & $278.4^{\mathrm{B}} \pm 6.8$ & $258.0^{\mathrm{C}} \pm 7.6$ & $292.2^{\wedge} \pm 6.2$ \\
\hline Specific density, $\mathrm{kg} / \mathrm{m}^{3}$ & $1089.6^{\mathrm{B}} \pm 10.9$ & $1097.5^{\mathrm{B}} \pm 16.9$ & $1195.9^{\mathrm{B}} \pm 23.8$ \\
\hline \multicolumn{4}{|c|}{ Sample of seeds from harvests in 1993 : } \\
\hline lenght & $9.4^{\mathrm{B}} \pm 0.7$ & $12.0^{\mathrm{A}} \pm 0.9$ & - \\
\hline breadth & $8.5^{\mathrm{B}} \pm 0.6$ & $10.6^{\mathrm{A}} \pm 0.9$ & - \\
\hline thickness & $4.4^{\mathrm{B}} \pm 0.3$ & $5.1^{\mathrm{B}} \pm 0.5$ & - \\
\hline Mass of 1000 secds, g & $252.4^{\mathrm{C}} \pm 4.5$ & $466.2^{\wedge} \pm 10.2$ & - \\
\hline Specific density, $\mathrm{kg} / \mathrm{m}^{3}$ & $1230.3^{\mathrm{A}} \pm 21.9$ & $1198.7^{\mathrm{B}} \pm 17.7$ & - \\
\hline \multicolumn{4}{|c|}{$\begin{array}{l}\text { Sample of secds from harvests in } 1993 \text { : } \\
\text { Dimension, mm: }\end{array}$} \\
\hline lenght & $10.2^{A} \pm 0.7$ & $9.6^{\mathrm{B}} \pm 0.5$ & $9.5^{13} \pm 0.8$ \\
\hline breadth & $9.0^{A} \pm 0.6$ & $8.7^{\mathrm{B}} \pm 0.5$ & $8.4^{c} \pm 0.7$ \\
\hline thickness & $4.5^{\mathrm{C}} \pm 0.3$ & $5.1^{\mathrm{B}} \pm 0.5$ & $4.8^{\mathrm{B}} \pm 0.3$ \\
\hline Mass of 1000 seeds, $\mathrm{g}$ & $279.0^{B} \pm 3.1$ & $302.6^{\mathrm{A}} \pm 4.0$ & $265.8^{\mathrm{c}} \pm 4.2$ \\
\hline Specific density, $\mathrm{kg} / \mathrm{m}^{3}$ & $1162.0^{\mathrm{A}} \pm 12.2$ & $1134.9^{\mathrm{B}} \pm 14.0$ & $1146.4^{\mathrm{AB}} \pm 19.2$ \\
\hline
\end{tabular}

A, B, C - means with the same superscripts within a column are not significantly different by Duncan's multiple range test $P \leqslant 0.01$

the protein contents bcing an overall 3-4 percentage units lower. In our studies, the crude protein content was similar or even higher than reported by other authors (Prieto and Aguilera, 1985; Batterham et al., 1986; Donovan et al., 1991; Eggum et al., 1993). According to Cheeke and Kelly (1989), who compared the data from 12 experiments, low-alkaloid varieties of white lupin contained between 30.3 to $41.3 \%$ (average $34.4 \%$ ) crude protein.

Similarly as in the study by Smulikowska et al. (1995), we found that the seeds of newer varieties contained less crude fibre and somewhat more (by about $5 \%$ ) raw fat. The gross encrgy content of seeds, depending on variety and year of harvest, equaled from 17.74 to $19.95 \mathrm{~kJ} / \mathrm{kg}$. The alkaloid content of Wat seeds was close to or slightly over $1 \mathrm{mg} / \mathrm{g}$, while in the newer varieties (Hetman and Bardo) it was half this value. In the analyzed Polish varieties of low-alkaloid white lupin, especially in Hetman and Bardo, the alkaloid content was approximately equal to the average values determined in many Australian and 


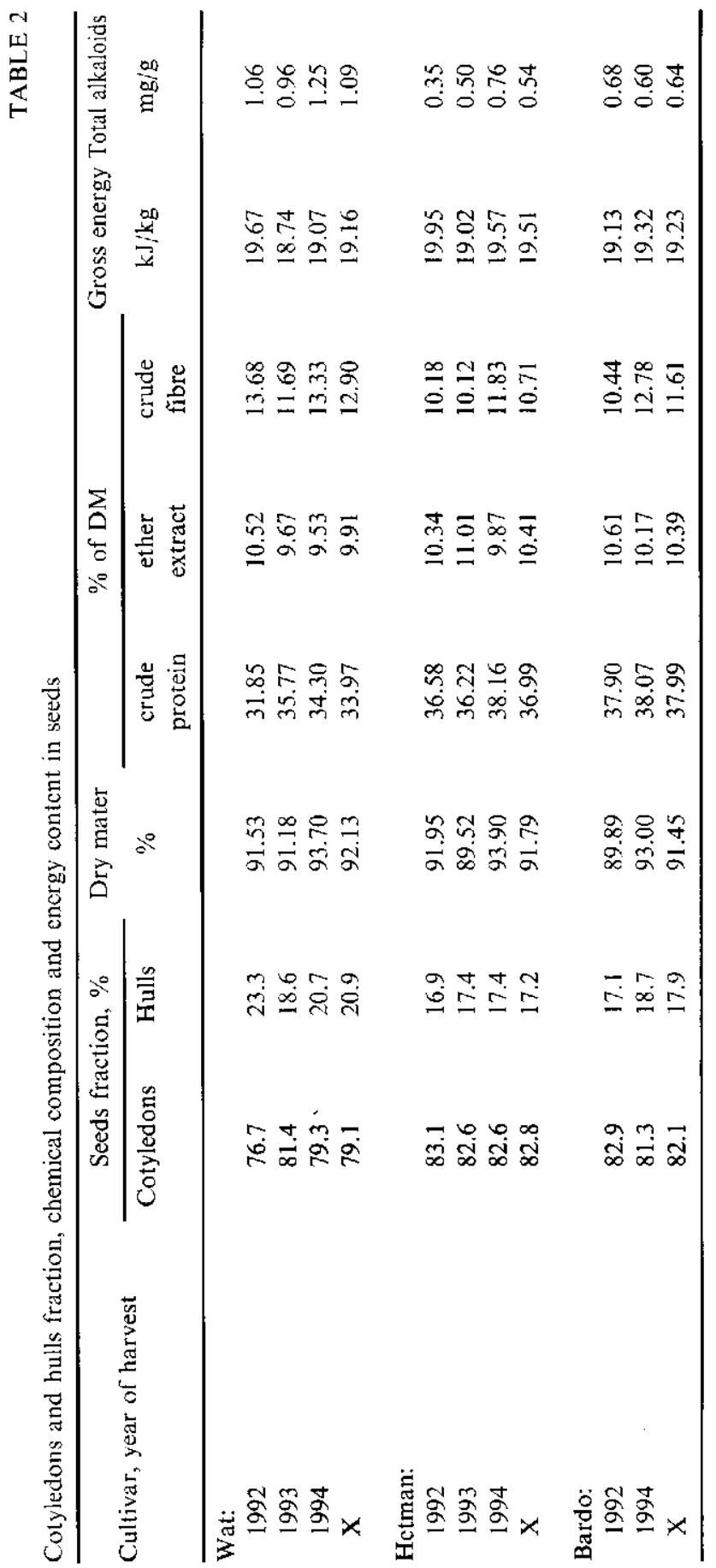




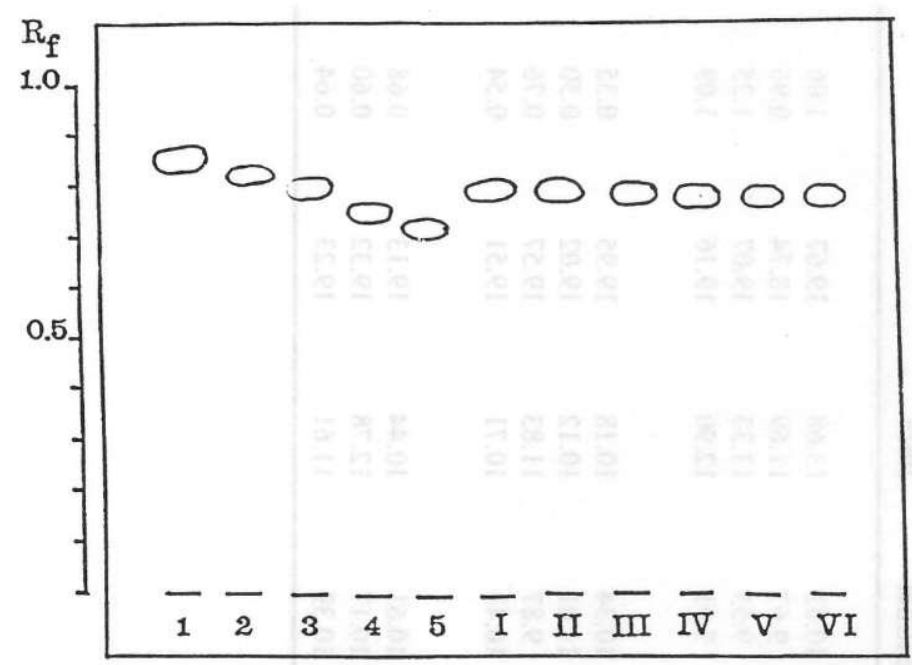

Figure 1. TLC of alkaloid extracts from the seeds of the studied varieties from two different harvest years.

Standards: 1 - sparteine, 2 - lupanine, 3-13-hydroksylupanine, 4-multiflorine, 5 - angustiflorine Seed extracts: Wat, I and II; Hetman, III and IV, Bardo, V and VI

European varieties of this species (Cheeke and Kelly, 1989). Similarly as in the case of seed size and weight, greater differences in alkaloid content, depending on year of harvest, were found in the Hetman variety. Somewhat smaller differences in the alkaloid content in the same varieties as reported in this paper were found by Buraczewska et al. (1993) and Alloui et al. (1994). The main alkaloids in the seeds were lupanine and 13-hydroxylupanine (Figure 1). The similar Rf of both alkaloids did not permit their mutual proportions to be determined. TLC did not reveal the presence of sparteine, multiflorine or angustifoline in the extracts. According to the data of other authors (Buraczewska et al., 1993; Hill and Pastuszewska, 1994), in addition to the dominant lupanine, 13-hydroxylupanine, multiflorine and seco-12,13-dihydromultiflorine are present in the varieties of white lupin.

Analysis of the chemical composition of white lupin seed fractions (cotyledons and seed coat) shows that by dehulling the seeds it is possible to increase the protein concentration and decrease the fibre content in the dehulled seeds. The seed coat contained $3.9-5.8 \%$ crude protein, $1.3-1.8 \%$ raw fat, while fibre constituted about $80 \%$ (Table 3), including cellulose and hemicellulose. The content of a given fibre fraction depended on the analytical method used and equaled: raw fibre, $52-56 \%$, ADF, $64-68 \%$, NDF, $73-80 \%$. These values were somewhat lower than those found by Smulikowska et al. (1995) and closer to the fibre content determined in white lupin seed coat by Yanez et al. (1990). 
TABLE 3

Chemical composition of whole seeds, cotyledons and hulls, \% DM

\begin{tabular}{|c|c|c|c|c|c|c|}
\hline \multirow{3}{*}{ Seed fractions, components } & \multicolumn{6}{|c|}{ Cultivar, year of harvest } \\
\hline & \multicolumn{2}{|c|}{ Wat } & \multicolumn{2}{|c|}{ Hetman } & \multicolumn{2}{|c|}{ Bardo } \\
\hline & 1993 & 1994 & 1993 & 1994 & 1992 & 1994 \\
\hline \multicolumn{7}{|l|}{ Whole seeds: } \\
\hline crude protein & 35.77 & 34.30 & 36.22 & 38.16 & 37.90 & 38.07 \\
\hline ether extract & 9.67 & 9.53 & 11.01 & 9.87 & 10.61 & 10.17 \\
\hline crude fibre & 11.69 & 13.33 & 10.12 & 11.83 & 10.44 & 12.78 \\
\hline ADF & 15.42 & 18.41 & 15.51 & 15.45 & 14.72 & 16.42 \\
\hline NDF & 17.76 & 19.87 & 17.80 & 18.01 & 17.58 & 16.72 \\
\hline cellulose & 13.09 & 16.76 & 13.17 & 13.83 & 12.52 & 14.88 \\
\hline hemicellulose & 2.34 & 1.46 & 3.01 & 2.56 & 3.17 & 0.30 \\
\hline lignin & 2.36 & 1.65 & 2.34 & 1.62 & 2.20 & 1.54 \\
\hline DF & 39.56 & 39.06 & 35.82 & 37.48 & 36.78 & 38.17 \\
\hline \multicolumn{7}{|l|}{ Hulls } \\
\hline crude protein & 4.36 & 4.41 & 3.87 & 5.80 & 4.05 & 5.03 \\
\hline ether extract & 1.45 & 1.33 & 1.48 & 1.32 & 1.83 & 1.30 \\
\hline crude fibre & 54.20 & 58.68 & 51.67 & 54.81 & 54.35 & 55.92 \\
\hline ADF & 64.31 & 68.39 & 64.29 & 65.03 & 64.21 & 66.01 \\
\hline NDF & 73.40 & 80.18 & 73.50 & 76.11 & 74.30 & 77.64 \\
\hline cellulose & 61.55 & 64.33 & 60.94 & 60.86 & 60.48 & 62.21 \\
\hline hemicellulose & 9.09 & 11.79 & 9.21 & 11.08 & 10.09 & 11.63 \\
\hline lignin & 2.76 & 3.95 & 3.35 & 4.17 & 3.75 & 3.80 \\
\hline DF & 79.76 & 80.25 & 79.49 & 80.37 & 81.06 & 82.11 \\
\hline \multicolumn{7}{|l|}{ Cotyledons } \\
\hline crude protein & 40.93 & 41.82 & 42.46 & 44.86 & 43.87 & 45.70 \\
\hline ether extract & 10.32 & 12.10 & 12.53 & 11.70 & 11.69 & 12.30 \\
\hline crude fibre & 1.05 & 1.65 & 1.09 & 1.94 & 1.53 & 1.90 \\
\hline $\mathrm{ADF}$ & 4.34 & 4.38 & 3.50 & 3.21 & 3.25 & 4.34 \\
\hline NDF & 5.29 & 4.96 & 6.51 & 4.53 & 6.42 & 4.68 \\
\hline cellulose & 4.34 & 4.38 & 3.50 & 3.21 & 3.25 & 4.34 \\
\hline hemicellulose & 0.95 & 0.58 & 2.29 & 1.32 & 2.86 & 0.34 \\
\hline lignin & nd & nd & nd & nd & nd & nd \\
\hline DF & 25.34 & 29.40 & 25.11 & 27.10 & 26.80 & 25.21 \\
\hline
\end{tabular}

No differences were found in the composition of seeds coat among varieties. For this reason, the differences in the composition of dehulled seeds (cotyledons) were similar to the differences among whole seeds. As the result of dehulling, the crude protein content rose from $34-38 \%$ in whole seeds to $41-46 \%$ in dehulled seeds. A similar difference between dehulled and whole seeds was found by other authors (Perez-Escamilla et al., 1988; Yanez, 1990; Smulikowska et al., 1995). Dehulled seeds contained small amounts of raw fibre and ADF, NDF, cellulose and hemicellulose, respectively. Similar differences in the raw fibre contents of 
TABLE 4

Mineral composition of seeds

\begin{tabular}{|c|c|c|c|c|c|c|}
\hline \multirow{3}{*}{ Components } & \multicolumn{6}{|c|}{ Cultivar, year of harvest } \\
\hline & \multicolumn{2}{|c|}{ Wat } & \multicolumn{2}{|c|}{ Hetman } & \multicolumn{2}{|c|}{ Bardo } \\
\hline & 1993 & 1994 & 1993 & 1994 & 1992 & 1994 \\
\hline $\mathrm{Ca}, \mathrm{g} / \mathrm{kg}$ & 3.43 & 4.04 & 2.94 & 3.16 & 3.53 & 3.02 \\
\hline $\mathrm{P}, \mathrm{g} / \mathrm{kg}$ & 4.56 & 3.51 & 3.73 & 3.31 & 4.26 & 2.85 \\
\hline $\mathrm{Mg}, \mathrm{g} / \mathrm{kg}$ & 1.48 & 1.75 & 1.82 & 1.90 & 1.49 & 1.46 \\
\hline $\mathrm{Mn}, \mathrm{g} / \mathrm{kg}$ & 0.81 & 0.45 & 1.45 & 0.44 & 0.90 & 0.69 \\
\hline $\mathrm{Fe}, \mathrm{mg} / \mathrm{kg}$ & 44.47 & 93.81 & 43.62 & 32.13 & 41.07 & 49.23 \\
\hline $\mathrm{Zn}, \mathrm{mg} / \mathrm{kg}$ & 40.24 & 43.23 & 53.12 & 43.12 & 47.26 & 43.29 \\
\hline $\mathrm{Cu}, \mathrm{mg} / \mathrm{kg}$ & 7.14 & 5.00 & 5.78 & 4.67 & 5.53 & 4.77 \\
\hline
\end{tabular}

whole and dehulled white lupin seeds were found by Perez-Escamilla et al. (1988): NDF equaled 20.0 and $8.8 \%$, respectively, ADF, 15.9 and $7.2 \%$ and cellulose, 13.6 and $4.5 \%$. In our study we found that enzyme-resistant cell wall components, denoted as dietary fibre, were still a significant component of dehulled seeds, constituting about 25 to $29 \%$ DM.

Large but not specific intervarietal differences in mineral contents, especially of $\mathrm{Mn}, \mathrm{Fe}$ and $\mathrm{Cu}$ were found (Table 4). It can be assumed that the soil and climatic conditions were the most important determinants in this case. In the two white lupin varieties analyzed by Donovan et al. (1991) the content of the studied elements also varied: $\mathrm{P}, 3.6$ and $4.6 \mathrm{~g} / \mathrm{kg}, \mathrm{Zn}, 17$ and $33 \mathrm{mg} / \mathrm{kg}, \mathrm{Fe}, 20$ and 55 $\mathrm{mg} / \mathrm{kg}$ and $\mathrm{Mn}, 0.30$ and $1.01 \mathrm{~g} / \mathrm{kg}$. In our study, we found a relatively high and variable $\mathrm{Mn}$ content, from 0.44 to $1.45 \mathrm{~g} / \mathrm{kg}$. Both extreme values were found in the seeds of the same variety, Hetman. The seeds of white lupin cultivated in Australia (Batterham et al., 1986; Cheeke and Kelly, 1989) contained much more $\mathrm{Mn}(1.8-3.8 \mathrm{~g} / \mathrm{kg})$. It is believed that the Mn content in sceds which does not lead to exceeding a $1000 \mathrm{ppm}$ level of $\mathrm{Mn}$ in the entire diet, should not depress the growth of pigs (Cheeke and Kelly, 1989).

\section{CONCLUSIONS}

Relatively large differences in the chemical composition of low-alkaloid white lupin seeds were found to depend both on the variety and year of harvest. The new variety Hetman and newest variety Bardo have a lower seed coat proportion, lower alkaloid and higher total protein contents. Dehulling leads to a significant increase in total protein content, and decrease of the content of fibre fractions in the dehulled seeds. 


\section{REFERENCES}

Aguilera J.F., Molina E., Prieto C., 1985. Digestibility and encrgy value of sweet lupin seed (Lupinus albus var. multolupa) in pigs. Anim. Feed. Sci. Technol. 12, 171-178

AOAC, 1990. Official Methods of Analysis of the Association of Official Analytical Chemists, $15^{\text {th }}$ Edition, Chapter 32

Alloui O., Smulikowska S., Chibowska M., Pastuszewska B., 1994. The nutritive value of lupin seeds (L. Luteus, L. angustifolius and L. albus) for broiler chickens as affected by varicty and enzyme supplementation. J. Anim. Feed Sci. 3, 215-227

Asp N.G., Johansson C.G., Hallmer H., Siljeström M., 1983. Rapid enzymatic assay on insoluble and soluble dictary fibre. J. Agric. Food Chem. 31, 476-482

Batterham E.S., Andersen L.M., Lowe R.F., Darnell R.Г., 1986. Nutritional value of lupin (Lupinus albus) seed meal for growing pigs: availability of lysine, effect of autoclaving and net energy content. Brit. J. Nutr. 56, 645-659

Buraczewska L., Pastuszewska B., Smulikowska S., Wasilewko J., 1993. Response of pigs, rats and chickens to dietary level of alkaloids of different lupin species. In: T.F.B. van der Poel, J. Huisman, H.S. Saini (Fititors), Recent Advances of Research in Antinutritional Factors in Legume Seeds, Wageningen Pers., EAAP Publication No. 70, 371-376

Checke P.R., Kelly J.D., 1989. Metabolism, toxicity and nutritional implications of quinolizidine (lupin) alkaloids. In: J. Huisman, T.F. B. van der Poel, I.F., J.iner (Editors), Recent Advances of Research in Antinutritional Factors in Legume Seeds, Pudoc, Wageningen 189-201

Donovan B.C., Me Niven M.A., Mac Leod J.A., Anderson D.M., 1991. Protein quality of two cultivars of lupin seeds evaluated in weanling rats. Anim. Feed Sci. Technol. 33, 87-95

Eggum B.O., Tomes G., Beames R.M., Datta F.U., 1993. Protein and energy evaluation with rats of seeds from 11 lupin cultivars. Anim. Feed. Sci. Technol. 43, 109-119

Flis M., Lewicki Cz., Tywończuk J., Meller Z., 1989. Evaluation of nutritive value of new varieties of different legume seeds in feeding of fatteners. I1. Production effects and after-slauhgter carcass quality (in Polish). Acta Acad. Agricult. Olst. 7oot. 32, 85-97

Fuchs B.. Fritz Z., Orda J., Krzywicki S., 1983. Comparison of nutritive value of faba bean, lupine and pea seeds in porkers feeding (in Polish). Zesz. Nauk. AR Wroclaw, Zoot. 140, 103-111

Hill G.D., Pastuszewska B., 1993. Lupin alkaloids and their role in animal nutrition, In: T.F.B. van der Poel, J. Huisman, H.S. Saini (Editors), Recent Advances of Research in Antinutritional Factors in Legume Seeds, Wageningen Pers., LAAP Publication No. 70, 343-362

Múzquiz M., Cuadrado C., Ayet G., Cuadra C., Burbano C. and Osagie A., 1994. Variation of alkaloids component of lupin seeds in 49 genotypes of Lupinus albus L. from different countries and locations. J. Agric. Food Chem. 42, 1447-1450

Pągowska E., 1990. Lupinus luteus, L. angustifolius, I. albus. Synthesis results of variety of experiments 1989 (in Polish). COBORU, Słupia Wielka, 901

Perez-Escamilla R., Vohra P., Klasing K., 1988. Lupins (Lupinus albus var. Ultra) as a replacement for soybean meal in diets for growing chickens and turkey poults. Nutr. Rep. Intern. 38. 583-593

Prieto C., Aguilera J.F., 1986. The effect of the supplementation with methionine and lysine of diets based on lupin seed (Lupinus albus var. multolupa) on protein and energy utilization in growing rats. J. Anim. Physiol. Anim. Nutr. 55. 239-246

Smulikowska S., Wasilewko J., Micczkowska A., 1995. A note on the chemical composition of the cotyledons and seed coat of three species of sweet lupin. J. Anim. Feed Sci. 4, 69-76

Socst van P.J., Wine R.H., 1967. Use of detergents in the analysis of fibrous fecds. IV. Determination of plant cell-wall constituents. J. Assoc. Ofr. Anal. Chem. 50, 50-55

Stahl F., 1969. Thin-layer Chromatography. A. Laboratory Handbook, Springer-Verlag 1969. 
Święcicki W., 1993. Selected problems of lupin genetics, In: Lupin in Human Economy and Life. Polish Lupin Society, Poznań, pp. 23-39

Wasilewko J., Pastuszewska B., Ochtabińska A., Buraczewska L., 1995. Amino acid composition and biological value of the proteins of three lupin species. Proceedings of 2 nd European Conference on Grain Legumes, Copenhagen, p. 273

Wysocka W., Brukwicki T., Jaloszyński R., Hoffmann K., 1989. A new and efficient method of extraction of alkaloids from lupin sceds. Lupin Newsletter 13, 59-65

Yanez E., 1990. Lupin as a source of protein in human nutrition. Proceedings of $6^{\text {th }}$ International Lupin Conference, Temuco-Pucon (Chole), pp. 115-123

Zduńczyk Z., Juśkiewicz J., Frejnagel S., Flis M., Godycka I., 1994. Chemical composition of the cotyledons and seed coat and nutritive value of whole and hulled seeds of yellow lupin. J. Anim. Feed Sci. 3, 141-148

\section{STRESZCZENIE}

Skład chemiczny i wartość pokarmowa nasion niskoalkaloidowych odmian lubinu białcgo 1. Charakterystyka nasion, liścieni i okrywy nasiennej

Na podstawie analiz prób nasion ze zbiorów w latach 1992-1994, scharakteryzowano wielkość, masę i skład chemiczny nasion oraz liścieni i okrywy nasiennej trzech polskich, niskoalkaloidowych odmian łubinu białego - Wat, Hetmana i Bardo. W starszej odmianic Wat przcciętny udział okrywy nasiennej był bliski $21 \%$, a zawartość białka ogólnego wynosiła $34 \%$ suchej masy. W nowszych odmianach Hetmana i Bardo stwierdzono mniejszy udział okrywy nasiennej (ok. 18\%), a większą zawartość białka ogólnego, odpowiednio 37 i $38 \%$ s.m. Zawartość alkaloidów w nasionach odmiany Wat była bliska $1 \mathrm{mg} / \mathrm{g}$, natomiast w nowych odmianach była przeciętnie dwukrotnie mnicjsza. Stwierdzono duże różnice w zawartości podstawowych skladników pokarmowych oraz alkaloidów w zależności od roku zbioru nasion. Usunięcie okrywy nasiennej powodowało wzrost udziału białka w nasionach obłuszczonych do 41-46\% s.m. i wyraźne zmniejszenie zawartości włókna. Stwierdzono duże, niezależne od odmiany lubinu, różnice w zawartości makro- i mikroclementów, a szczególnie $\mathrm{Mn}, \mathrm{Fe}$ i Cu. Zawartość Mn w nasionach była stosunkowo duża, od 0,44 do 1,45 g/kg. 